\title{
Clinical Social Workers: Advocates for Social Justice
}

\author{
Anne Marie McLaughlin
}

\begin{abstract}
Advocacy activities provide an avenue for all social workers to connect their practice with the profession's aim of social justice. In fact, it is this social justice connection to the advocacy role that may distinguish social work from other professions. Yet advocacy remains a controversial practice for many clinical social workers. This study reports on one aspect of a larger study (McLaughlin, 2006), which examined how clinical social workers in mental health conceptualized social justice as part of their work. The data revealed a strong relationship exists between clinical social work practice, social justice and advocacy. The concept of advocacy that emerged from the data was multi-dimensional and included strategies that were instrumental, educational, and practical.
\end{abstract}

Keywords: Advocacy, social justice, mental health

\section{INTRODUCTION}

Although in the past clinical social workers have been maligned by their own profession in terms of their commitment to social justice (Andrews \& Reisch, 2002; Hawkins, Fook \& Ryan, 2001; Specht \& Courtney, 1994), current practice models tackle social justice issues head on. Such frameworks as anti-oppressive practice, feminist practice, and narrative and constructionist models consider contextual issues such as culture and gender, as well as social, economic and political imbalances (Morley, 2003; Parker, 2003; Swenson, 1998; Vodde \& Gallant, 2002). Yet suspicions regarding clinical workers' commitment to social justice persist. For many, practice models and frameworks are insufficient and students and practitioners alike wonder exactly what the link between their practice and social justice might be.

Results of a recent qualitative inquiry into clinical work and social justice (McLaughlin, 2006) revealed that participating mental health social workers overwhelmingly identified advocacy efforts — with and on behalf of clients—as strategies for social justice. That inquiry posed three questions: 1) how do mental health social workers conceive of social justice; 2) how do they incorporate social justice in their work, and; 3) what barriers do they encounter. This paper reports on one aspect of the larger study, specifically, the predominant way in which participants incorporate social justice into their work. The data revealed a strong relationship exists between clinical social work practice, social justice and advocacy. The concept of advocacy, as described by practitioners, was multi-dimensional and included strategies that were instrumental, educational, and practical.

Anne Marie McLaughlin, Ph.D., is an assistant professor of Social Work at the University of Calgary.

Copyright (C) 2009 Advances in Social Work Vol. 10 No. 1 (Spring 2009), 51-68 


\section{Social justice and Advocacy}

Advocacy is a well-established strategy for achieving social justice (Gehart \& Lucas, 2007; Hoefer, 2006; Kiselica \& Robinson, 2001; Miley, O’Melia \& DuBois, 2007). Moreover, advocacy is considered a professional obligation (Hepworth, Rooney \& Larson, 2002). National and international professional social work bodies entrench professional social work practice, advocacy and social justice through their codes of ethics (British Association of Social Workers, 2002; International Federation of Social Workers, 2004; National Association of Social Workers, 2008). The Canadian Association of Social Workers (2005) explicates the link between advocacy and social justice:

Social workers advocate for fair and equitable access to public services and benefits. Social workers advocate for equal treatment and protection under the law and challenge injustices, especially injustices that affect the vulnerable and disadvantaged. (CASW, 2005)

Many studies have explored the connection between social justice and advocacy (Bowes \& Sim, 2006; Kiselica \& Robinson, 2001; Miley et al., 2007; Mitchell \& Lynch, 2003; Van Voorhis \& Hostetter, 2006), and agree that advocacy strategies provide powerful "tool[s] for challenging social injustice” (Dalrymple, 2004, p. 188; Kiselica \& Robinson, 2001). While the connection between advocacy and social justice is sometimes indirect (Johnson, 1999), advocacy activities provide an avenue for all social workers to connect their practice with the profession's aim of social justice (Wakefield, 1988a, 1988b). In fact, it is this social justice connection to the advocacy role that may distinguish social work from other professions (Butler \& Webster, 2003; Ezell, 1994; Hoefer, 2006, Reamer, 1998).

Advocacy is often represented in the literature as a strategy more closely aligned with macro or policy practice (Wolfer \& Gray, 2007). However, social workers in direct practice are intimately involved in many aspects of individual client lives, including financial, cultural, medical, legal and spiritual issues, and are therefore able to assess and intervene in many areas in which injustice may occur. The advocacy role appears to be a hand-in-glove fit with generalist practice (Hoefer, 2006; Kirst-Ashman \& Hull, 2006; Walker, 2004). Yet, most current generalist practice text books make scant reference to the role of advocacy in social work practice (Compton, Galaway \& Cournoyer, 2005; Heinonen \& Spearman, 2006; Miley et al., 2007; Poulin, 2005; Segal, Gerdes \& Steiner, 2007; Sheafor \& Horejsi, 2008). Further, little attention to advocacy or social action can be found in undergraduate curricula. When evidence of advocacy instruction emerges it falls primarily in community development courses, which frequently are optional for students (Radian, 2000). This has led some to wonder if social work's "tradition of advocacy for social and economic justice has fallen prey to benign neglect” (Mitchell \& Lynch, 2003, p. 14). 


\section{Advocacy: Form and Function}

The concept of advocacy varies both in form and function. In form, advocates can be paid professionals, as in the case of patient advocates in mental health or child welfare systems (Herbert \& Mould, 1992). The citizen advocate is another form of advocacy where non-professionals volunteer time to help another (Hunter \& Tyne, 2001; Rapaport, Manthorpe, Hussein, Moriarty \& Collins, 2006). Self-advocacy is an important contribution to the advocacy movement with deep roots in the disability field. Empowerment forms the cornerstone of self-advocacy where individuals build skills and gain strength to advocate for themselves (Buchanan \& Walmsley, 2006; Walker, 2004). Within generalist practice advocacy is considered a technique or skill, typically a subset of case management (Compton, Galaway \& Cournoyer, 2005; Hepworth, Rooney \& Larson, 2002; Hoefer, 2006; Miley et al., 2007).

Historically, advocacy has been divided into case and cause (Carlisle, 2000; Compton, Galaway \& Cournoyer, 2005; Miley et al., 2007; Sheafor \& Horejsi, 2008). Cause advocacy addresses systemic issues and involves lobbying efforts aimed at policy or institutional restructuring. Cause (sometimes referred to as class) advocacy has as its goal "to advance the cause of a group in order to establish a right or entitlement to a resource or opportunity" (Sheafor \& Horejsi, 2008, p. 425). This form of advocacy has been closely allied with policy practice and other forms of macro social work.

In case advocacy, the aim is to redress power imbalances and promote the rights of individuals who are marginalized or vulnerable (Carlisle, 2000). Narrowly defined case advocacy "assure[s] that the services or resources to which an individual client is entitled are, in fact, received" (Sheafor \& Horejsi, 2008, p. 55). This definition appears weak and does not distinguish itself from case management or other types of service delivery (Herbert \& Levin, 1996). Social workers advocating for resources may find clients require more than they are entitled to, depending on who has established the entitlement. A more robust definition rejects entitlement and emphasizes need. For instance case advocacy implies intervention when available services are not relevant to needs or when an organization is not responsive to those needs (Herbert \& Levin, 1996).

Advocacy can be directly related to clinical work through a common goal, that is, "helping clients become independent and exercise influence and control over their own lives” (Lens \& Gibelman, 2002, p. 614). Contemporary social work practice models have moved beyond individualistic problem-focused perspectives and attend to issues of power, culture, social and economic injustices (Finn \& Jacobson, 2003). In the current global climate of job and financial insecurity where individuals and groups have shrinking access to resources and opportunities, advocacy takes on greater urgency not only within macro approaches to social work but also within direct practice (Walker, 2004)

Although advocacy appears to be a central role for social workers, many authors are extremely cautious and somewhat ambivalent in supporting its implementation. For instance, Forbat and Atkinson (2005) doubt social workers' ability to separate client needs from organizational demands and to speak against colleagues. Shearfor and Horejsi 
(2008) caution that class advocacy is not for everyone, especially those who feel uncomfortable with confrontation. Compton, Galaway and Cournoyer (2005) are even more cautious and raise flags for those contemplating class advocacy saying that practitioners "risk infringing upon the self-determination of those for whom [they] claim to speak. Who is the client? Who decides the purpose and objectives of your actions?” (p. 128). They also ask social workers to reflect on who suffers if they are successful in achieving their ends. The warning to social workers is to think through ethical obligations to individual clients before pursuing structural and systemic change (Compton, Galaway \& Cournoyer, 2005). Controversy continues around the relationship between clinical work and advocacy for social justice (Egan, 2007).

This controversy impacts practice. Despite the relevance of advocacy in theory, in practice advocacy is not as common as it would seem (Davis, Baldry, Milosevic \& Walsh, 2004; Ezell, 1994; Herbert \& Levin, 1996; Lens \& Gibelman, 2000; Nelson, 1999). For instance Nelson (1999) found that frontline workers in her study ranked advocacy last out of five commonly performed functions. In a similar study, social workers in an Australian hospital ranked advocacy ninth out of eleven identified functions (Davis et al., 2004; Davis, Milosevic, Baldry \& Walsh 2005). Similarly Ezell (1994) evaluated time spent in advocacy activities and discovered that $90 \%$ of responding social workers $(n=353)$ indicated some advocacy activities within their regular employment. However, the actual number of hours involved in advocacy was low (less than five hours per week for the majority).

Social justice as well as advocacy are both considered professional and ethical obligations, yet few studies have explored with practitioners how these may be linked in practice. Clinical social workers and those in direct practice carry the same professional and ethical obligations to work for social justice but may feel limited in their opportunities. This study explores how participants expressed social justice in their work.

\section{METHOD}

In this qualitative research study 18 social workers from a western province in Canada were sampled. Purposeful sampling was used for the first five participants. These participants were considered to be information-rich sources (Patton, 2002). They were selected for their practice experience in mental health and their interest in social justice, as demonstrated through their participation in their professional association. Snowball sampling, with participants providing the names of potential additional participants, provided the remainder of the sample. Participants identified themselves as clinical social workers (considered the standard for practioners working in mental health in this province), had earned an MSW degree and were employed in various aspects of a provincially funded mental health system. Nine participants worked on in-patient wards or programs including geriatric psychiatry, forensic psychiatry, mental health administration, and a brain injury unit. Two participants worked as outreach psychiatric emergency/crisis workers, six participants worked in community clinics, and one worked in a day program. 
Participant interviews lasted between 1 and 1.5 hours and were conducted at the convenience and discretion of each interviewee either at their place of work $(n=13)$ or at an agreed upon location. Interviews were transcribed and coded using familiar qualitative processes (Strauss \& Corbin, 1998). Computer assisted qualitative data management software (QSR International, NVivo 7) was utilized for data management and retrieval.

The results reported in this paper comprise one element of a larger research project which explored the meaning participants brought to the term social justice and how that meaning was translated into practice (McLaughlin, 2006). Grounded theory methodology was utilized and the concept of advocacy emerged early as an in vivo category representing participants expression of social justice in their work. The author initially resisted this concept in part, because of received ideas, preconceived notions, assumptions and conceptualizations already surrounding advocacy. Eventually, the author began to think of advocacy as a sensitizing concept (Bowen, 2006; Charmaz, 2006; Glaser, 1978). Rather than resist the term, advocacy was used to explore participants' meaning in depth.

Data analysis proceeded according to the constant comparison method in which each slice of data is compared to each other slice (Glaser \& Strauss, 1967). Analysis and data collection proceed together and the researcher is guided by what emerges. As mentioned, the theme of advocacy emerged early in the data analysis and each incident and each sentence were compared against each other. Throughout the interview process, as well as the analysis, the researcher stayed open to variations, interpretations and applications. In later interviews the author became sensitized to discussion concerning advocacy and used more probes when this discussion arose. The author also returned to earlier interviews, once advocacy was identified as a sensitizing concept, to reexamine the texts with fresh awareness.

To ensure the trustworthiness of the findings the author employed several techniques (Cohan \& Crabtree, 2008; Creswell, 1998). The author attempted to maintain a reflexive stance toward the data by way of memo writing and peer debriefing. Memos were written following individual interviews as well as throughout the data analysis process. The author met with a peer team throughout the research and writing process to share themes as they emerged and to discuss possible research bias and assumptions as well as to review possible connections between concepts and categories. The analyst also sought negative cases as a way of exploring and accounting for all the data.

Eventually, a conceptual framework for advocacy emerged representative of the participants' experience. While generalization to the larger population is not a goal of qualitative research, identifying and describing patterns of behavior in a specific context is. This tentative conceptualization expands and enlarges on previous iterations of the concept of advocacy and relates particularly to clinical social workers in mental health. 


\section{FINDINGS}

\section{Advocacy}

The concept of advocacy captures significant variation in the ways in which participating social workers worked for social justice. At times advocacy appeared to be a proxy for social justice, as one worker expressed, "I think [advocacy] would be the closest thing to embodying social justice at a practice level in clinical social work". Advocacy also served as a direct example of social justice: "when I am advocating, I am aiming for a target that I think everybody deserves... In a sense I am seeking justice for this person.” The goal of advocacy, as the next participant explains, is the realization of social justice, "anytime I go to an appeal [with my client], the person that is appealing feels (and I would not appeal it if I did not believe) that they were achieving some sort of social justice.”

Regardless of the meaning of social justice for participants, the most frequent manifestation of social justice appeared through advocacy activities. Advocacy goals and strategies, according to participants, are both broad and varied, encompassing micro (aimed at a particular individual), mezzo (aimed at a particular group of people, such as the mentally ill, or those living in poverty), and macro levels (activities aimed at betterment of all society such as a fair minimum wage, clean water, or access to health care). A number of strategies were identified at each level. These strategies and dimensions are listed in part in Table 1.

Three types of advocacy are embedded in the data: instrumental advocacy, educational advocacy, and practical advocacy. Instrumental advocacy concerns particular actions taken by the study participants on behalf of clients. Educational advocacy involves heightening awareness of social justice issues, rights, needs, and opportunities, not just for clients but also for colleagues or the public at large. Practical advocacy involves working with clients directly to access resources, such as in accompanying them to appeals or even filling out documentation that is posing a barrier to the access of resources. These three types of advocacy are listed below.

Instrumental advocacy. In some situations requiring advocacy activities, clients may be unable to take direct action themselves, either as a result of their marginalized status, or because of particular challenges they face. For instance, in the following scenario, the social worker working on a geriatric psychiatric ward describes her advocacy work for seniors who resist institutionalization:

When anyone at that age isn't functioning the way they should, everyone wants them placed somewhere that is secure so that nobody has to worry about them. That's the big thing. I have been a very strong advocate of risk, and allowing people to live in risk if they are competent to understand the risk. 
Table 1: $\quad$ Advocacy Strategies and Dimensions

\begin{tabular}{|c|c|c|c|}
\hline & Individual & Marginalized Groups & Just Society \\
\hline $\begin{array}{l}\text { Instrumental } \\
\text { Holding } \\
\text { systems } \\
\text { accountable }\end{array}$ & $\begin{array}{l}\text { - lobby on behalf of } \\
\text { - ensuring } \\
\text { accountability } \\
\text { - liaison between } \\
\text { services }\end{array}$ & $\begin{array}{l}\text { - letter writing } \\
\text { - demonstrations } \\
\text { - marches } \\
\text { - program } \\
\text { development }\end{array}$ & $\begin{array}{l}\text { - campaign for } \\
\text { social issues } \\
\text { e.g. living } \\
\text { wage } \\
\text { - professional } \\
\text { association } \\
\text { work }\end{array}$ \\
\hline $\begin{array}{l}\text { Educational } \\
\text { Educating } \\
\text { individuals, } \\
\text { families, } \\
\text { colleagues, } \\
\text { society }\end{array}$ & $\begin{array}{l}\text { - } \text { educating } \\
\text { individuals about } \\
\text { rights, options or } \\
\text { choices, the } \\
\text { system } \\
\text { - educating others } \\
\text { about } \\
\text { needs/rights, } \\
\text { stigma }\end{array}$ & $\begin{array}{l}\text { - } \text { committee work } \\
\text { - } \text { anti-poverty groups } \\
\text { - } \text { school systems } \\
\text { - multidisciplinary } \\
\text { teams } \\
\text { - Public education } \\
\text { initiatives }\end{array}$ & $\begin{array}{l}\text { - Public health } \\
\text { awareness } \\
\text { strategies, } \\
\text { AIDS, Mental } \\
\text { Health }\end{array}$ \\
\hline $\begin{array}{l}\text { Practical } \\
\text { engaged in } \\
\text { action }\end{array}$ & $\begin{array}{l}\text { - assist by filling } \\
\text { out forms } \\
\text { - accompany to } \\
\text { appeals or } \\
\text { interviews } \\
\text { - locating housing }\end{array}$ & $\begin{array}{l}\text { - volunteer work for } \\
\text { food bank, HIV } \\
\text { network } \\
\text { - volunteer on crisis } \\
\text { line }\end{array}$ & $\begin{array}{l}\text { - run for } \\
\text { political office }\end{array}$ \\
\hline
\end{tabular}

In the next example, a community mental health social worker advocates for children he is counseling who are drifting in the foster care system. Instrumental advocacy on the part of this social worker involves contacting a client's child welfare worker in an effort to see service improve and hold systems accountable:

[It was a] child welfare case and children who were taken from the home and placed with another family member, hadn't had contact with their parents, I think it was for four weeks. I know that ... the child welfare worker had every intention to have the children return to live with their family, but for whatever reason the children hadn't met with their parents in perhaps four weeks. To me that was just ludicrous from the point of view of the child's perspective, strictly...I get upset about it, I can't believe that. ...The children have rights, the children weren't informed of anything, they had no idea what was going on. And so I [got] in touch with [the worker]. 
Working on behalf of others occurs frequently, in particular with vulnerable populations. Instrumental advocacy involves engaging with other systems to secure rights and resources. In the next example a mental health social worker describes institutional constraints that adversely affect her client:

Often the challenge in these facilities is lack of staff, and there was a client who was in the later stages of multiple sclerosis, and she had depression which is why we were involved. Through doing the assessment I had a chance to speak with her husband, and he had informed me that his wife wasn't getting fed enough and he had some concern around that. When I approached the care manager of the facility, she expressed that there are a certain amount of hours per resident per a 24 hour time period that residents were entitled to. When someone is in the later stage of MS, everything is time consuming because they are extremely heavy care. And so the reality was, from the perspective of this care manager, that there simply wasn't enough time for her to be fed completely, and so the staff would do what they could and then they had to move on.

The worker, on behalf of the client and her family, advocated for a humane response from an unyielding bureaucracy. Respondents frequently indicated that they are firsthand witnesses to bureaucratic injustice that place unnecessary constraints on individuals. Respondents know these systems and often challenge the injustices they meet. The next participant, a mental health worker for inner city residents, explains:

I have to fight with social services financial benefits workers for little things. For example, a fellow who has a decent work history, but has a horrific past that has kind of caught up with him, so he has gotten depressed and suicidal.... He needs life skills and how to deal with stress and anger and conflict and managers and so on. He had good potential for that, and so the occupational therapist set him up in a sheltered workplace out of [a local] hospital, a very good wood working shop. He has not enough money to get there by bus, and so we have had to fight for the last three months for them to fulfill their own regulations about giving him enough money for bus fare to get to this.

This participant recognizes the injustice facing the client and advocates vigorously on his behalf.

Educational advocacy. Educational advocacy concerns efforts social workers engage in on behalf of a particular client or client group, with the goal of influencing others in the direction of social justice. As one respondent noted, "you keep trying to educate the system about the population." In institutional settings clinical social workers use sensitivity and skill to influence other members of the multi-disciplinary team around issues of social justice, without alienating others, as this respondent illustrates:

Our team [has] a good reputation and I think a lot of that is because we really try to work collaboratively with staff. We don't come in there and try to tell them what to do, because they have enough of that. We are there to listen to their concerns and try and do a little bit of negotiation between the needs of the 
residents and resources of staff, and trying to get them to look at things at a different slant.

This worker emphasizes that the goal of her advocacy is to influence. She is attempting to shift institutional attitudes. Respondents recognize that environmental conditions and a problem focus within institutions negatively impact staff's ability to view each client as unique and valued. Advocacy, in this instance, means directing the attention of others away from the problem focus of classification and toward a more human understanding of the individual and their particular needs.

Other strategies employed by respondents include: attempting to encourage more client input in decisions affecting them, or finding a more equitable allocation of resources based on needs rather than protocol. Education advocacy attempts to influence those within the system, as one respondent pointed out: "it's some of the people working in the system that need to be educated and taught an attitude change." Education advocacy includes educating others about issues that oppress or stigmatize:

When I am spending extra hours every year doing [awareness] activities-going on TV, radio, newspaper articles-why I am doing that is because my clients say that they feel stigmatized in the community and they want people to understand more about brain injuries so they can feel more a part of society. I am being motivated by social justice values in doing that, not because I like to be on TV.

Bringing issues of social justice to the awareness of colleagues is part of advocacy work. Social workers in this study are familiar with how attitudes and judgments can negatively impact access to resources:

We need to bring it to people's awareness, that this is a social justice issueawareness among other health care providers. Now a days, we deal a lot with judgment-we can't get away from the fact that a lot of health care providers come from a privileged position, so they get attitudes and judgments around what is the right way to do something and whether or not somebody should be allowed to do thus or so. [for example] 'you can't let them go back home to live such and such a life'.

Educational advocacy also includes educating clients about their own rights within the system so they "can access systems and situations in better ways that they might not have come up with by themselves," as one participant explains. This advocacy strategy views knowledge as power and empowerment as informed decision-making. Educating clients to the system is part of empowerment:

Clinically, if you are not writing policy and you are not doing any of that stuff, so you're not doing social justice, I think that's false. I think on an individual level, knowledge is power, by providing somebody with all the information of the mental health act, all the help available to them, the good and bad parts of medication, the good and bad parts of accepting this diagnosis.... The fact that you do not have to accept this label, and I will say that to people that they don't. 
Practical advocacy. Practical advocacy is typified by clinical social workers assisting individual clients in various ways: assisting with an application for funding, accompanying clients to appeals or interviews and, on some occasions, much more. For some individuals with chronic mental illness it may mean that the worker must take an active role in assisting as the following worker describes:

... accompanying ... patients to interviews to ensure that they are properly heard and understood when they are in an interview. It's a vulnerable population, and they often get overwhelmed by so many questions or questions they can't answer, and we're able to be there to rephrase questions for them, to ensure that they are heard. A lot of them don't have the confidence and skill to present themselves well during an interview.

The next participant describes his practical efforts with a client who was turned down for financial benefits:

I helped him when the time was right to apply for [assistance]. He was turned down partly, or mostly, based on his history being a drug user and all that. It was not based on the fact that he had become quite disabled, physically and cognitively, and needed the support that he was supposed to have a right to. I did the appeal for him, went to the appeal with him, and made the case that he have equal access to [assistance] as anybody else. I brought his mother in to help make the case, we won the appeal, and he got his [money] and was able to live a reasonable quality of life.

By giving practical and often hands-on assistance the workers in conjunction with clients achieve justice for their clients.

\section{Barriers}

Advocacy as a strategy for social justice is not without challenges. Advocacy for social justice may be blocked within organizations and not viewed as "part of the job" that social workers were hired for: "I don't think I have ever been at a table where social justice or social action has been the primary objective." Social workers who embrace the advocacy role may find themselves marginalized or discounted as others tire of the message:

You're sort of going against the stream when all around you people seem to say,

"We're not listening". ...So what happens is, after a while, you have to sort of back off, because it becomes, "Well, that's [the social worker] and that's the way that she sees things."

Social workers fear being stereotyped. One respondent, adept at accessing scarce resources for clients, expresses resentment at being seen only as "the resource girl." She also expresses concern for social workers who advocate for resources: "We're the resource people... I have had to spend the last two years proving that I have some value, that I have some knowledge base, first of all. I am very conscious of the fact that I am not just the resource girl.” In this instance participants also find themselves advocating for their professional identity. 
Advocacy efforts may also be seen as misguided due to a lack of appreciation of the larger issues. Not all participants valued individual advocacy efforts: "the advocacy that I've seen done... consisted of lower level case by case stuff when the problems were up here.”

Beyond this, social workers are also faced with philosophical questions regarding whether or not to engage those they work for in a political battle for social justice. The mental health population is vulnerable and frequently is already shouldering additional burdens such as poverty and stigma. Some participants question the ethics of politicizing clients in their own quest for social justice, and are concerned about the implications of advocacy when and if workers start to drive the agenda.

A related dilemma is the concern that by making social justice the priority, the real mental health treatment issues may be eclipsed. Focusing on societal change could compromise issues for the individual. Advocating for wholesale change may seem misguided:

To me that advocacy role would be more about changing society, and that's what I think the danger is, that idealistically and philosophically buying into an idea about how things should be, and then going out and trying to do it. I think it's really dangerous because you are not looking at the individual situations, and it could overstep what really needs to take place.

For this participant, the focus in clinical work has to be on the individual. Advocating for group issues may jeopardize the needs of the individual, "I think that everybody has to be treated individually around these issues, not as a group, "cause that sort of supersedes everything. When you group people together, you don't see the diversity.”

\section{DISCUSSION}

This study extends the discussion of advocacy to better reflect and capture advocacy strategies employed by participating mental health social workers pursuing social justice. The case/cause dichotomy does not adequately do justice to the breadth of activities employed by participants in this study. The proposed typology sees advocacy as having three functions: instrumental, education and practical. Each of these functions can be practiced at the level of the individual, group, community or societal level. Advocacy strategies described here comprise an integral component of direct social work practice and need not be seen as a separate skill set (Hoefer, 2006).

Hoefer (2006) defines social work advocacy as, "That part of social work practice where the social worker takes action in a systematic and purposeful way to defend, represent, or otherwise advance the cause of one or more clients at the individual, group, organizational or community level, in order to promote social justice” (p. 8). This definition fits well with what participants in this study have described. Yet, many research studies report that advocacy in practice is lagging behind other social work functions such as assessment, counseling, resourcing, and consulting (Ezell, 1994; Nelson, 1999). Considering the close association between advocacy and pursuit of social 
justice, and, considering the desire on the part of the profession to strengthen efforts to affect social justice, greater emphasis on advocacy seems timely.

Based on the findings from this study it is possible to propose a framework for advocacy by clinical social workers and to more clearly delineate the connection these practices have with the pursuit of social justice. Making the connection between advocacy and social justice explicit could increase commitment and provide impetus for practitioners to enhance and hone their advocacy skills. Van Voorhis and Hostetter (2006) argue that increased self-confidence and competence with advocacy increases an individual's commitment to the process. Social workers who feel empowered are better equipped to advocate with and on behalf of clients. Like participants in this study it is possible that not all social workers are clear about the connection between social justice and advocacy.

\section{Advocacy's Connection to Social Justice}

In order to connect advocacy as described here with the social justice mission of the social work profession, we must first consider the meaning of social justice. This is no easy task as the meaning of social justice not only changes with the times but may change depending on the context (Reisch, 1998; 2002). Two prominent interpretations of social justice familiar to social workers are distributive justice as articulated by Rawls (1971) and the politics of identity as expressed by Young (1990). From the distributive paradigm, issues of access to resources and the fair and equitable distribution of scarce resources are central. In addition, social justice is concerned with fair and just procedures and treating individuals with dignity and respect. Social workers pursue fair and just procedures for distribution of social goods and hold governments and agencies accountable for this. Distributive social justice stipulates that each individual is entitled to a minimum of basic social goods: liberty, wealth, opportunity, and also, self-respect (Rawls, 1971).

We can see that participants in this study are, in fact, conscious of and concerned with distributive issues of social justice. Participants pursed fair and equitable access to resources with and on behalf of their clients. They worked hard to hold systems accountable and ensure needs were met. They encountered unjust procedures and advocated with and on behalf of those they worked with. They pursued care for individuals that respected the dignity and worth of those they served. Within the mental health system as with many bureaucracies dehumanizing and unjust practices persist. A social worker's ability to advocate with and on behalf of clients, individually or collectively, is important work that confronts injustice and seeks change.

The politics of identity conceives of social justice differently. Here social justice is not limited to the distribution of social goods. Rather the central concern is with how individuals and groups are valued or devalued in society and how existing social structures: values, attitudes, behaviors and beliefs, support and perpetuate these positions (Young, 1990). The result of these valued and devalued positions is domination and oppression; one group is privileged while another is suppressed-male over female, able bodied over disabled, rich over poor. Marginalization, exploitation, and powerlessness 
occur as individuals are shut out from decision-making (Young, 1990). Tackling injustice from this perspective requires challenging the domination of ideas, values, beliefs and behaviors of one group over another.

Those accessing services within the mental health system may find themselves marginalized and powerless, cut out of decision-making, unable to advocate on their own because of stigma, a debilitating illness or temporary incapacitation, overwhelmed by the many social and institutional injustices they face. Clinical social workers can use advocacy strategies to change attitudes, secure resources, reduce stigma, defend cultural identities, remove barriers, and ensure discounted voices are heard. Healing and health require more than counseling and support, they require attention to attitudes, values, and practices that oppress and constrain individuals from fully participating in society (Gomez \& Yassen, 2007; Pearlmutter, 2002).

Advocacy strategies with the aim of social justice include educating individuals about their rights: rights to service, rights to resources, rights to respect, rights to appeal, and rights to refuse treatment. Instrumental, educational and practical components of advocacy may challenge the way some social workers have viewed direct practice. The obligation to be an advocate pushes workers to get involved. Advocacy requires the acknowledgment that many constraints and limitations that individuals experience are not the result of personal or mental deficits but are real limits imposed by unjust environments. Social workers are adept at understanding the interplay between the person and their environment and it is this perspective that motivates workers and facilitates a social justice perspective.

\section{Concerns}

Some participants expressed reservations about the social justice agenda and its impact on clients. Others noted that a focus on social justice may overshadow the real concerns of mental health clients. Still others maintain that while they value the role of advocate and feel obligated to speak out with and on behalf of clients, they sense that this role may not be valued by others such as colleagues and employers. This can lead to the marginalization of some workers as well as resistance and push-back from organizations (Greene \& Latting, 2004). These are real ethical and practical issues that cannot be ignored. However, workers in this study have found ways and means to be both an advocate and maintain employment. In part, as one participant noted, workers must make judgments about what strategies to pursue, and when. More discussion among practitioners and students, regarding the challenges and opportunities for incorporating advocacy for social justice into direct practice is required. Practitioners and students alike report an interest in bettering their skills (Gomez \& Yassen, 2007).

\section{CONCLUSION}

Participants in this study clearly identified advocacy strategies as their best efforts to link clinical practice with social justice; advocacy with and on behalf of clients to access resources, increase opportunities and reduce barriers and stigma. On one hand, advocacy

in clinical practice is obviously part of how social workers, those in direct practice and 
others, view good social work practice (Herbert \& Levin, 1996). On the other hand, reports from the practice literature indicate that as a component of practice it is underutilized. The challenge for clinical social workers and those in direct practice is to find ways to work for social justice and to respect the individual needs of clients. Integrating advocacy into practice poses specific challenges. These challenges are practical as well as ethical and deserve further exploration.

Within the social work curriculum advocacy has not received the attention it requires in order to become a more effective and relevant component of practice. Advocacy needs to come out of the macro and policy classes and be fully integrated into clinical and direct practice course work. Social justice and the code of ethics require that all social workers develop the skills and knowledge to recognize and overcome injustice. Yet, social workers appear to face resistance to advocacy activities.

On a practical level we need to know more about how to support advocacy practice in the field. Do employers view advocacy activities by clinical social workers in a positive light? Is advocacy even valued as a practice strategy in any mental health job description? Practice research indicates that although not a top priority for social workers in terms of job functions, advocacy is a relevant and legitimate component of most mental health practice. The need for highly developed advocacy skills and knowledge is well recognized as vulnerable individuals increasingly find themselves overwhelmed and underserved by complex social systems (Bronstein, Kovacs \& Vega, 2007; Levy \& Payne, 2006).

Finally, this paper has delineated three crucial components of advocacy activities: educational, practical, and instrumental. By identifying these specific components of advocacy, educators and practitioners may be able to increase awareness and skills related to advocacy in social work and thereby better meet their social justice aims.

\section{References}

Andrews, J., \& Reisch, M. (2002). The radical voices of social workers: Some lessons for the future. Journal of Progressive Human Services 13(1), pp.5-30.

Bowen, G. (2006). Grounded theory and sensitizing concepts. International Journal of Qualitative Methods, 5(3), 1-9

Bowes, A., \& Sim, D. (2006). Advocacy for black and minority ethnic communities: Understandings and expectations. British Journal of Social Work, 36, 1209-1225.

British Association of Social Workers (2002). The ethics of social work: principles and standards. Retrieved December 2008 from http://www.basw.co.uk/Portals/0/CODE\%200F\%20ETHICS.pdf.

Bronstein, L., Kovacs, P., \& Vega, A. (2007). Goodness of fit: Social work education and practice in health care. Social Work in Health Care, 45(2), 59-76.

Buchanan, I., \& Walmsley, J. (2006). Self-advocacy in historical perspective, British Journal of Learning Disabilities, 34, 133-1. 
Butler S., \& Webster, N. (2003). Advocacy techniques with older adults in rural environments. Journal of Gerontological Social Work, 41(1-2), 59-74.

Canadian Association of Social Workers (2005). Code of Ethics. Retrieved October 7, 2005 from http://www.casw-acts.ca/.

Carlisle, S. (2000). Health promotion, advocacy and health inequities: A conceptual framework. Health Promotion International, 15(4), 369-376.

Charmaz, K. (2006). Constructing grounded theory: A practical guide through qualitative analysis. London: Sage.

Cohan, D., \& Crabtree, B. (2008). Evaluative criteria for qualitative research in health care: Controversies and recommendations. Annals of Family Medicine, 6(4), 331339.

Compton B., Galoway, B., \& Cournoyer, B. (2005). Social work processes ( $7^{\text {th }}$ ed.). Pacific Grove, CA: Brooks/Cole Publishing.

Creswell, J. W. (1998). Qualitative inquiry and research design: Choosing among five traditions. Thousand Oaks, CA: Sage Publications.

Dalrymple, J. (2004). Developing the concept of professional advocacy: An examination of the role of child and youth advocates in England and Wales. Journal of Social Work, 4(2), 179-197.

Davis, C., Baldry, E., Milosevic, B., \& Walsh, A. (2004). Defining the role of the hospital social worker in Australia. International Social Work, 47(3), 346-358.

Davis, C., Milosevic, B., Baldry, E., \& Walsh, A. (2005). Defining the role of the hospital social worker in Australia: Part 2. A qualitative approach. International Social Work, 48(3), 289-299.

Egan, G. (2007). The skilled helper ( $8^{\text {th }}$ ed.). Belmont, CA: Thomson Brooks/Cole.

Ezell, M. (1994). Advocacy practice of social workers. Families in Society: The Journal of Contemporary Human Services, 75(1), 36-47.

Finn, J., \& Jacobson, L. M. (2003). Just practice: Steps toward a new practice paradigm. Journal of Social Work Education, 39(1), 57-78.

Forbat, L., \& Atkinson, D. (2005). Advocacy in action: The troubled position of advocates in adult services. British Journal of Social Work, 35, 321-335.

Gehart, D., \& Lucas, B. (2007). Client advocacy in marriage and family therapy: A qualitative case study. Journal of Family Psychotherapy, 18(1), 39-56.

Glaser, B. (1978). Theoretical sensitivity: Advances in the methodology of grounded theory. Mill Valley, CA: The Sociology Press.

Glaser, B., \& Strauss, A. (1967). Discovering grounded theory: Strategies for qualitative research. Chicago: Aldine Publishing Company. 
Gomez, C., \& Yasson, J. (2007). Revolutionizing the clinical frame: Individual and social advocacy practice on behalf of trauma survivors. Journal of Aggression, Maltreatment \& Trauma, 14(1-2), 245-263.

Greene, A. D., \& Latting, J. K. (2004). Whistle-blowing as a form of advocacy: Guidelines for the practitioner and organization. Social Work, 49(2), 219-230.

Hawkins, L., Fook, J., \& Ryan, M. (2001). Social workers' use of the language of social justice. British Journal of Social Work, 31, 1-13.

Heinonen, T., \& Spearman, L. (2006). Social work practice: Problem solving and beyond $\left(2^{\text {nd }}\right.$ ed.). Toronto, CA: Tompson/Nelson.

Hepworth, D. H., Rooney, R. H., \& Larsen, J. A. (2002). Direct social work practice: Theory and skills ( $6^{\text {th }}$ ed.). Pacific Grove, CA: Brooks/Cole.

Herbert, M., \& Levin, R. (1996). The advocacy role in hospital social work. Social Work in Health Care, 22(3), 71-83.

Herbert, M., \& Mould, J. (1992). The advocacy role in public child welfare. Child Welfare, 71(2), 114-130.

Hoefer, R. (2006). Advocacy practice for social justice. Chicago: Lyceum Books Inc.

Hunter, S., \& Tyne, A. (2001). Advocacy in a cold climate: A review of some citizen advocacy schemes in the context of long-stay hospital closures. Disability and Society, 16(4), 549-561.

International Federation of Social Workers. (2004). Ethics in social work, Statement of principles. Retrieved December 2008 from http://www.ifsw.org/en/p38000015.html.

Johnson, Y. (1999). Indirect work: Social work’s uncelebrated strength. Social Work, 44(4), 323-334.

Kirst-Ashman, K., \& Hull, G. (2006). Understanding generalist practice (4 ${ }^{\text {th }}$ ed.). Belmont, CA: Thomson Brooks/Cole.

Kiselica, M. S., \& Robinson, M. (2001). Bringing advocacy counseling to life: The history, issues, and human dramas of social justice work in counseling. Journal of Counseling \& Development, 79(4), 387-397.

Lens, V., \& Gibelman, M. (2000). Advocacy, be not forsaken: Retrospective lessons from welfare reform. Families in Society, 18(6), 611-620.

Levy, J., \& Payne, M. (2006). Welfare rights advocacy in a specialist health and social care setting: A service audit. British Journal of Social Work, 36, 323-33.

McLaughlin, A. M. (2006). Clinical social work and social justice. Dissertation Abstracts International. The Humanities and Social Sciences, 6(11), 4337.

Miley, K. K., O’Melia, M., \& DuBois, B. (2007). Generalist social work practice: An empowerment approach ( $5^{\text {th }}$ ed.). Boston: Allyn \& Bacon. 
Mitchell, J., \& Lynch, R. S. (2003). Beyond the rhetoric of social and economic justice: Redeeming the social work advocacy role. Race, Gender \& Class, 10(2), 8-26.

National Association of Social Workers (2009). Code of ethics of the National Association of Social Workers. Retrieved March 25, 2009 from http://www.naswdc.org/pubs/code/code.asp.

Nelson, M. (1999). A view of hospital social work advocacy in hospitals in Eastern Ontario. Social Work in Health Care, 29(4), 69-92.

Parker, L. (2003). A social justice model for clinical practice. Affilia, 18(2), 272-288.

Patton, M. Q. (2002). Qualitative evaluation and research methods (3 ${ }^{\text {rd }}$ ed.). Newbury Park: Sage.

Pearlmutter, S. (2002). Achieving political practice: Integrating individual need into social action. Journal of Progressive Human Services, 13(1), 31-51.

Poulin, J. (2005). Strength-based generalist practice: A collaborative approach. Belmont, CA: Brooks/Cole-Thompson Learning.

QSR International Pty Ltd. (2008, Version 8) NVivo qualitative data analysis software.

Radian, E. (2000). Social action and social work education in Canada. (Doctoral Dissertation, University of Calgary, 2000). University Microfilm International, National Library of Canada, 0-612-54806-6.

Rapaport, J., Manthorpe, M., Hussein, S., Morarty, J., \& Collins, J. (2006). Old issues and new directions: Perceptions of advocacy, its extent and effectiveness from a qualitative study of stakeholder views. Journal of Intellectual Disabilities Research, 10(2), 191-210.

Rawls, J. (1971). A theory of justice. Oxford: Oxford University Press.

Reamer, F. G. (1998). Ethical standards in social work practice: A review of the NASW code of ethics. Washington, DC: NASW Press

Reisch, M. (1998). The sociopolitical context and social work method, 1890-1550. Social Service Review, 72(2), 161-181.

Reisch, M. (2002). Defining social justice in a socially unjust world. Families in Society: The Journal of Contemporary Human Services, 83(4), 343-354.

Segal, E., Gerdes, K., \& Steiner, S., (2007). An introduction to the profession of social work: Becoming a change agent. Belmont, CA: Brooks/Cole Publishing.

Sheafor, B.W., \& Horejsi, C. R. (2008). Techniques and guidelines for social work practice $\left(8^{\text {th }}\right.$ ed.). Boston: Allyn $\&$ Bacon.

Specht, H., \& Courtney, M. (1994). Unfaithful angels: How social work has abandoned its mission. New York: The Free Press. 
Strauss, A., \& Corbin, J. (1998). Basics of qualitative research: Techniques and procedures for developing grounded theory $\left(2^{\text {nd }}\right.$ ed.). Thousand Oaks, CA: Sage Publications.

Swenson, C. R. (1998). Clinical social work's contribution to a social justice perspective. Social Work, 43, 527-537.

Van Voorhis, R., \& Hostetter, C. (2006). The impact of MSW education on social worker empowerment and commitment to client empowerment through social justice advocacy. Journal of Social Work Education, 42(1), 105-121.

Vodde R., \& Gallant J. P. (2002). Bridging the gap between micro and macro practice: Large scale change and a unified model of narrative-deconstructivist practice. Journal of Social Work Education, 38(3), 439-458.

Wakefield, J. C. (1988a). Psychotherapy, distributive justice, and social work Part 1: Distributive justice as a conceptual framework for social work. Social Service Review, 62(2), 187-211.

Wakefield, J. C. (1988b). Psychotherapy, distributive justice, and social work Part 2: Psychotherapy and the pursuit of justice. Social Service Review, 62(3), 353-382.

Walker, S. (2004). Community work and psychosocial practice: Chalk and cheese or birds of a feather? Journal of Social Work Practice, 18(2), 161-175.

Wolfer, T., \& Gray, K. (2007). Using the decision case method to teach policy advocacy. Journal of Teaching in Social Work, 27(1-2), 37-59.

Young, I. M. (1990). Justice and the politics of difference. Princeton, NJ: Princeton University Press.

\section{Author's note:}

Address correspondence to: Anne Marie McLaughlin, Ph.D., Assistant Professor, Central and Northern Region, University of Calgary, Faculty of Social Work. \#444, 11044-82 Avenue, Edmonton, Alberta, T6G 0T2. Email: am7@ualberta.ca. 